\title{
The Role of Caucus Feto Iha Politika in Increasing Women's Representation in Timor-Leste's Parliament
}

\author{
Muhammad Ammar Hidayahtulloh ${ }^{1}$ \\ mrafazan@gmail.com
}

\begin{abstract}
Woman had been neglected from the political affairs in the early of post-independent era. It raised the concerns of women activists on political participation. They realized Timorese women had played a significant role in fighting for independence along with male veterans. Caucus Feto Iha Politika appears as the prominent NGO in Timor-Leste that promoting gender equality in politics. It resulted the rising of women's representation in Timor-Leste Parliament significantly. Moreover, its woman participation in parliament achieves the highest percentage in the Asia Pacific. This research lies on the question of how does the role of Caucus Feto Iha Politika in increasing women's representation in parliament of Timor-Leste. The data obtained from primary and secondary sources by conducting the in-depth interview and library research. In order to answer the research question, the authors reiterated the three main components of NGOs roles -implementer, catalyst, and partner by Lewis as the analytical framework. The authors humbly concluded that for increasing the number of women MPs, Caucus Feto Iha Politika played two prominent roles, as follows: 1) catalyst, by advocating the policy change of women-friendly legislative quota policy to the Government of Timor-Leste, and 2) partner, by working closely with the related stakeholders to increase the capacity of potential female candidates and elected women MPs through capacity building. Keywords: Caucus Feto Iha Politika, Gender, NGO, Political Participation, Timor Leste
\end{abstract}

\section{Introduction}

The Timorese women did not directly enjoy the equal political rights as their male veterans partner did in the post-independent era. The exclusion of women from political affairs led to the underrepresentation of women in politics. The highrank male veterans during the resistant time dominated the political leadership and heads of state institutions - executive, legislative and judiciary (Ospina, Participation of Women in Politics and Decision Making in Timor-Leste: A Recent History, 2006). During the administration of the United Nations Transitional Administration in East Timor (UNTAET), the Gender Affairs Unit (GAU) was established on April 2000. The GAU aimed at ensuring the gender issues are addressed during the UNTAET administration (Ospina, 2006). This situation led to the rise of women's movements in Timor-Leste, and eventually the First National Women's Congress was held on June

\footnotetext{
${ }^{1}$ Korespondensi : ASEAN Studies Center Universitas Muhammadiyah Yogyakarta. Kampus Terpadu UMY Jl. Brawijaya, Kasihan, Bantul, Yogyakarta 55183
} 
2000 with 500 women attended the congress and successfully devised the Platform of Action for the Advancement of Timorese women. The proposal of 30\% quota policy for women in parliament became the national agenda (Asian Development Bank, 2005). It was first proposed to the National Council in preparing the 2001 election of Constituent Assembly. Yet, the proposal was rejected and the fight for quota policy was continued. The congress also set up a national women's network named Rede Feto. Rede Feto is an umbrella organization for women's organizations in TimorLeste, which currently comprising of 34 member organizations (Exposto, 2019). Rede Feto has the main role to facilitate, coordinate, and strengthen the member organizations to advance the status of women in Timor-Leste (Asian Development Bank, 2014). The member organizations of Rede Feto have the various sectors to work on in order to bring gender equality in all sectors (Exposto, 2019). In regard to the political sector, Caucus Feto Iha Politika (hereinafter called Caucus) is one among the Rede Feto's member organizations which was established in 2001 that becomes the forefront in promoting the equal political rights for women and increasing the women's participation in politics at all levels ever since.

In 2003, as the consequence of the pressures from local women's organizations and international community, Timor-Leste's Government demonstrated its commitment in promoting and advancing women's rights in Timor-Leste by ratifying the Convention on the Elimination of All Forms of Discrimination against Women (CEDAW) without reservation and the Optional Protocol to CEDAW (NGOs Working Group on CEDAW Alternative Report, 2009). Following the ratification of CEDAW, Timor-Leste also complies with the 1995 Beijing Platform for Action (BPfA). In conjunction with those efforts, this country with the struggle from the women's movements has made a notable progress in gender equality, particularly in increasing women's representation in parliament. Since 2001 election until the 2018 election, the number of women who elected as the MPs underwent the upward trend. Currently, Timor-Leste becomes the country with the highest number of women's representation in parliament in Asia Pacific, in which women made up 40\% of the total seats in parliament. The local women's organizations are considerably contributive to and are the reason of such achievement. 
This article is aimed at exploring to what extent the role of women NGOs in Timor-Leste especially Caucus in increasing the women's representation in parliament of Timor-Leste. The article rests on several sections. The first section, the authors provides the literature review on the NGOs study as well as women's representation. In the following section, the authors describe the research methodology. In the third section, the authors present the results/findings related to the historical context of Caucus and its programs and projects. Additionally, the authors offer the overview of women's political participation and representation in Timor-Leste as well as the electoral system and law. The fourth section, the authors discuss the results/findings by analyzing the roles of Caucus in regard to political participation of women in Timor-Leste. Eventually, the last section is the conclusion.

\section{Literature Review}

As the world is modernized and globalized, the enormous number of nongovernmental organizations (NGOs) has emerged rapidly over the past decades. It is unneglectable that the research and study on NGOs followed along the way and has increased over the times (Kareithi \& Lund, 2012). Conceptually speaking, NGOs are a commonly used terminology to describe the third-sector which characterized as voluntary, non-government, and non-profit (Lewis \& Kanji, 2009). The term NGOs was introduced globally by the United Nations (UN) as the organizations which work internationally, contextually belong to developing country and awarded to organizations that gained consultative status in UN activities (United Nations, 2007).

In relations to development, NGOs is recognized to play a greater role started in the late 1980s. The presence of NGOs in development becomes more significant due to the support from the international donor community, recognizing the inefficient and ineffective government to government aid and prevailing development project (Lewis, 2010). The huge amount of donor is delivered towards many NGOs at grassroots, national and even international level to carry out particular issue in regard to poverty reduction. Therefore, it is sufficient to recognize NGOs as the important actor in development ever since. In modern society, the development agenda set by the NGOs has introduced and raised the awareness on the variety of issues in recent years, such as human rights, gender, environment, social development, 
emergency response, democracy building, conflict resolution, and many others (Lewis \& Kanji, 2009).

The book authored by David Lewis entitled 'Non-Governmental Organizations, Management and Development' published in 2001 is the first book to disclose the management of NGOs (Elbers, 2016). A similar work also introduced by Helmut K. Anheier in a published book entitled 'Nonprofit Organizations: Theory, Management, and Policy' in 2005. Both Lewis and Anheir provide a comprehensive introduction to NGO, and hence to be used in this article for understanding the roles played by NGOs in both national and international level. Lewis (2001) summarized the three prominent roles played by NGOs in a broad sense, namely implementers, catalysts, and partners. First, the implementer role is understood as delivery of goods and services such as healthcare, credit, agricultural extension, legal advice or emergency relief. Second, the so-called catalysts role defined as the ability of NGOs to inspire, facilitate and contribute towards development through such activities like empowerment, lobbying and advocacy. Lastly, NGOs played a partner role which described as the ability of NGOs to co-work with government, donors, and private sectors in certain projects or activities. Those three roles classified by Lewis, has a similarity with the functions of NGOs explained by Krasmer (1981), those are serviceprovider, vanguard, value-guardian, and advocacy.

The empirical study on the roles of NGOs in particular sector has come to receive special attention from many scholars, such as NGO role in advocacy for human rights (Ilieva, 2006; Marcinkute, 2011), health (Omungo, 2011), governance (Leung, Leung, \& Yuen, 2016), security (Djuyandi, 2016), women's rights and gender issues (Everett, 2011; Alvarez, 1999; Nimu, 2018; Dibie \& Dibie, 2012), migrant workers' rights (Kim, 2011), and socio-economic development (Nyamugasira, 1998). Most of the aforementioned literatures focused on the advocacy roles of NGOs in specific sector in developing countries. The advocacy roles of NGOs also studied broadly in transnational level (Keck \& Sikkink, 1998; Keck \& Sikkink, 2002). The prominent argument is that the NGOs involved in the Transnational Advocacy Networks (TANs) which become a prominent actor in current global politics in advocating certain issues -women's suffrage, human rights, and environmental issues - which work 
transnationally. The Boomerang Pattern introduced by Keck \& Sikkink simply explains how the TANs work.

The linier study on the role of NGOs in regard to increase women's representation in parliament or the adoption of gender quota also can be addressed in some literatures (Hughes, Krook, \& Paxton, 2015; Demirdöğen, 2012). Hughes, Krook, \& Paxton (2015) summarized the theories to explain the quota policy adoption, such as the global pressure, domestic ties to transnational organizing, global-domestic interaction effects, regional and cross-regional exposure effects, and national characteristics. Among the summarized theories of quota policy, the active transnational women's activism increases the likelihood of quota policy adoption in national levels globally (Hughes, Krook, \& Paxton, 2015). Demirdöğen (2012) also explained that both international governmental organizations (IGOs) such as UN and international NGOs such the Socialist International played pivotal role in shaping the global norm of gender equality and creating mechanism concerning women's political representation. Meanwhile, widely speaking, the literature on gender quota in TimorLeste remains few in numbers (IDEA, 2003; Ospina, Participation of Women in Politics and Decision Making in Timor-Leste: A Recent History, 2006; Ballington \& Dahlerup, 2006; Cummins, 2011). By that, the authors believe that this article is significant to the study of both NGOs and women's political representation. This article offers the closure of the role of NGOs, particularly women NGOs in newly democratic country such as Timor-Leste in regard to the women's political representation in parliament.

\section{Methods}

The research methodology in this study is a qualitative method. The authors analyze the data and information from both primary and secondary sources. The primary data is obtained by conducting field observation and interview with reliable informants. Meanwhile, the secondary data is obtained by addressing relevant literatures through library research.

The authors directly observe the secretariat and activities of NGOs and related-institutions which is Rede Feto, Caucus Feto Iha Politika, Grupo das Mulheres Parlementares de Timor-Leste (GMPTL) or well-known as Parliamentary Women's 
Caucus. In addition, the authors also conduct the interview with some informants representing each organization, namely: Interim Executive Director of Rede Feto, Director of Organization Caucus Feto Iha Politika, and a woman Member of Parliament. The secondary data is gathered through accountable and reliable existing literatures of both NGOs and women's political representation. The books, journals, reports, government policy and law, as well as documents from website documented by authors in this article are referred in the bibliography.

\section{Results and Discussion}

\section{Caucus Feto Iha Politika: A Historical Context}

Historically speaking, the establishment of Caucus was in relations with the first election of Constituent Assembly in 2001. On 13 March 2001, the National Council rejected the quota policy proposal for Constituent Assembly elections which proposed by Rede Feto representatives and Deputy Speaker Milena Pires (Ospina, 2006). The UNTAET was claimed as the reason behind the rejection of quota policy, arguing it would violate the free and fair elections (Charlesworth \& Wood, 2002). It led to the women's protests who perceived women were underrepresented in politics. The proactive measures had been called to ensure the women's representation in the Constituent Assembly after the women's groups protest. As the result of the protest, the meeting between the women's group leaders and UN administrator and SRSG (Special Representative of Secretary General) was held on 15 March 2001 (Ospina, 2006). A day later on 16 March 2001, the UNTAET passed the Regulation on the Elections of a Constituent Assembly to Prepare for an Independent and Democratic East Timor (UNTAET/Reg No. 2001/2). The regulation was not made to specifically rule the reservation of seats for women in Constituent Assembly. Despite the absence of a clause on affirmative action in the regulation, the equal participation of men and women were still encouraged by giving the incentives to those political parties that promote women candidates (Ospina, 2006; Kemitraan Indonesia, 2014). In addition, SRSG also committed to organize the political leadership training for women through giving the mandate to the UNTAET GAU. 
"There was the political leadership training held by UNTAET GAU for political party members, and potential individuals. There were more than a bundred participants, with around 25 participants in each workshop, with the total 6 workshops. Each representative of the workshop session discussed about the importance of raising the awareness of women in politics. It was the beginning of the creation of Caucus Feto Iha Politika (Interview with Paula F. Corte Real de Aranjo, Director of Caucus, 9 January 2019)"

Caucus officially operated on 11 June 2001 with those women trainees became the members (Ospina, 2006). Working hand in hand with Rede Feto, Caucus gained a wide acknowledgement as the important actor in promoting the women's participation in politics not only as a voter, but also to run in the election as a candidate. At first, it was established as the concrete outcome of the political leadership training held by the UNTAET GAU for raising the awareness of women in politics and preparing potential female candidates to run in the election.

\section{Programs and Projects of Caucus Feto Iha Politika}

Since its establishment in 2001, Caucus has been contributed to increase the women's political participation and representation in Timor-Leste. It was only a week after it was operationalized, the representatives of Caucus visited the 13 districts in Timor-Leste. During the visit, it was organizing the similar training and workshop on political leadership for women, establishing the local women's caucus, and encouraging more women to run in the election (Ospina, 2006; Ospina, 2006). Eventually, Caucus had assisted the independent women candidates who run in the election to be endorsed at least by 100 people with the right to vote. There were three women who were able to collect the required least numbers of signatures to run in the election just in 2 days. Although at the end of the election none of those independent women candidates were elected to sit in Constituent Assembly, there were 22 women represented political parties won out of 88 seats elected (Caucus Feto Iha Politika, 2017). Regardless the result, it is important to highlight the effort of Caucus in raising the awareness of women voters. Otherwise, women might be more underrepresented in the Constituent Assembly. Moreover, the result of election was somehow considered a success for women, prominently after the National Council rejected the quota policy. 
Later after the Constituent Assembly elected, the program and/or project of Caucus are no longer about preparing independent women candidates, but on how to make sure that the elected women are treated equally and their voices are taken into consideration in decision-making process. After the transfer of Constituent Assembly to National Parliament in 2002, women MPs have been struggled to unite on various gender issues although gender equality has been guaranteed in the Constitution in the Section 16, 17, and 63 (Ospina, 2006; Asian Development Bank, 2005; Constitution of The Democratic Republic of TimorLeste, 2002). Therefore, Caucus advocated the establishment of parliamentary women's caucus to the National Parliament named Grupo das Mulheres Parlementares de Timor-Leste (GMPTL) in order to ensure that women MPs are able to unite on gender issues (Araujo, 2019).

"By establishing the women's caucus in parliament, the issues of women and gender will
receive special attention and therefore will ensure that all legislations passed by the
parliament consider the gender perspective and use CEDAW as its legal instrument
(Interview with Paula F. Corte Real de Araujo, Director of Caucus, 9 January 2019)"

Currently, Caucus is an active member of Rede Feto and also a part of Advocacy Working Group of Rede Feto along with other 6 member organizations. It becomes the one and only Rede Feto's member organization that concerns in politics. The programs and projects run by Caucus are such as advocacy, capacity building and media and public relations (Rede Feto, 2019). There are three main targets of Caucus in conducting their programs and projects for increasing the number of women's political participation and representation at all levels. Those are political parties, GMPTL, and potential women candidates (Araujo, 2019). Caucus maintains a good relation with GMPTL and also many political parties in Timor-Leste as well as other women's organizations. For instance, prior to the 2012 election, Caucus cooperate with Alola Foundation and Yayasan HAK to support women candidates (Araujo, 2019). In running their programs and projects, Caucus is supported financially by the Timor-Leste's Government since 2010 by utilizing the civil society fund under the Prime Minister with prevailing terms and conditions (Interview with Paula F. Corte Real de Araujo, Director of Caucus, 9 January 2019). 


\section{Women's Representation and Timor-Leste's Electoral System and Law}

The women's political representation in parliament becomes one of important issues in nation building and democratization process in Timor-Leste. In fact, it has always been increasing over the past decades since the first election organized under the UN administration. Table 1 shows the number of women MPs in the last four national parliaments. It is known that the UNTAET was claimed behind the rejection of quota policy as it would harm the fair and free election. However, since the beginning, the international community has never undermined the women's role in politics in Timor-Leste.

Table 1. Women MPs in Timor-Leste's Parliament (2002-2018)

\begin{tabular}{c|c|c|c|c|c|c|c}
\multicolumn{2}{r|}{2002} & \multicolumn{2}{c|}{2007} & \multicolumn{2}{c|}{2012} & \multicolumn{2}{c}{2018} \\
\hline $\begin{array}{c}\text { Women } \\
\text { MPs }\end{array}$ & $\begin{array}{c}\text { Total } \\
\text { MPs }\end{array}$ & $\begin{array}{c}\text { Women } \\
\text { MPs }\end{array}$ & $\begin{array}{c}\text { Total } \\
\text { MPs }\end{array}$ & $\begin{array}{c}\text { Women } \\
\text { MPs }\end{array}$ & $\begin{array}{c}\text { Total } \\
\text { MPs }\end{array}$ & $\begin{array}{c}\text { Women } \\
\text { MPs }\end{array}$ & $\begin{array}{c}\text { Total } \\
\text { MPs }\end{array}$ \\
\hline 22 & 88 & 19 & 65 & 25 & 65 & 26 & 65 \\
\hline$\%$ Women MPs & \multicolumn{2}{c|}{$\%$ Women MPs } & $\%$ Women MPs & $\%$ Women MPs \\
\hline \multicolumn{2}{c|}{$25 \%$} & \multicolumn{2}{c|}{$29.2 \%$} & \multicolumn{2}{c|}{$38.5 \%$} & \multicolumn{2}{c}{$40 \%$}
\end{tabular}

Source: (Ospina, 2006; Caucus Feto Iha Politika, 2017)

In the first election of 2001, women won 22 seats out of 88 contested seats in Constituent Assembly. Women had accounted for $25 \%$ of the total seat despite the rejection upon gender quota policy. The active efforts by women NGOs supported by UNTAET GAU made women possible to occupy a quarter of parliamentary seats. However, the policy design -electoral system and law, and political party remain crucial to the women's representation in parliament (Yoon, 2001; Schwindt-Bayer, 2009; Verge, 2012; Gwiazda, 2017). The introduction of gender quota policy also becomes the fast track and temporary special measures to increase women's representation in parliament (Dahlerup \& Freidenvall, 2005; Tripp \& Kang, 2008). Regarding this, in the case of Timor-Leste, it can be seen in the table 1 that there was an increase of women's representation in Timor-Leste's Parliament in 2007 up to 29.2\%. The Electoral Law No. 6/2006 of 28 December which became the legal basis for running the election was indicated as the cause of the increase of representation of women in the 2007 election. The existing General Election Law in Timor-Leste established the closed list proportional representation 
system which is the electoral system that is better for encouraging women's participation in politics (Kemitraan Indonesia, 2014). Furthermore, the law also granted one fourth of candidate list is a woman. In 2011, the 2006 Electoral Law was amended by the Electoral Law No. 7/2011 of 22 June whoich amended the Article 12 Section 3 to granting one third of effective and alternate candidates list is a woman. The law also gives the National Elections Commission or Comissão Nacional de Eleições (CNE) the power to disqualify the political party from participating in the election as if it does not put a woman candidate in every three candidates (Kemitraan Indonesia, 2014; Araujo, 2019). Consequently, in the following parliamentary elections in 2012 and 2018, the women's representation was significantly increased, in which women were accounted for $38.5 \%$ and $40 \%$ respectively (Asian Development Bank, 2014; Araujo, 2019). It concludes TimorLeste at the first rank in Asia Pacific as a country with the highest women's representation in Parliament.

\section{Role of Caucus Feto Iha Politika: A Catalyst and Partner}

It seems to be obvious that international community has promoted the norm of gender equality across the world. Yet, there is no such a smooth and easy process in the fight of gender equality, particularly in politics. In Timor-Leste's context, the concept of gender equality norm is new. But, the main idea of gender equality in itself had been practiced even decades before it gained its independence. During the resistant time, for instance, all the Timorese regardless of gender fought together to gain independence. Women were given an equal chance to go to battlefield as a nurse, teacher, and even field commander. But, the society does not really aware of such gender roles, and thus patriarchal culture and tradition remain as the constraint for the political participation of women. It can be seen through the existing male-dominated political parties in Timor-Leste which limits women to involve in decision-making process. Moreover, the political parties' view and behavior on women's political participation is also varied. There are some that supportive, and some challenge it.

As of today in Timor-Leste, women have gained $40 \%$ seat in National Parliament. What does really matter now is to question who is behind the impressive change of the National Parliament's structure in which becoming more 
and more gender balance. This article highlights Caucus as a prominent actor in addressing the challenge faced by Timorese women in the fight for political participation. In this section, the authors break down two main roles played by Caucus in promoting political participation and representation of woman, especially to increase the number of women MPs in Timor-Leste.

\section{a. Catalyst Role: Advocating the Amendment of Electoral Law}

Lewis (2001) described that NGO play what called as catalysts role to inspire, facilitate and contribute towards development through such activities like empowerment, lobbying and advocacy. In fact, advocacy is what Caucus does in increasing the number of women's representation in politics at all levels. The remarkable catalyst role of Caucus can be seen through the active involvement of Caucus in advocating the amendment of Electoral Law No. 6/2006 of 28 December prior to the 2012 parliamentary election. Nonetheless, it was not the one and only advocacy effort of Caucus in advocating women's political participation in Timor-Leste. In undergoing the advocacy effort, Caucus does not stand by itself, but rather to use Advocacy Working Group of Rede Feto to make it more efficient and impactful (Araujo, 2019).

In 2002, Caucus along with other stakeholders such as Rede Feto, IRI (International Republican Institute) and OPE (Office for the Promotion of Equality) now called SEIGIS (State Secretary for Gender Equality and Social Inclusion) advocated the key gender issues in National Parliament. Two years later, in 2004, some of women MPs gathered to propose the creation of Ad-hoc Commission for Gender Affairs, Equality, and Children. Yet, the proposal was rejected during the parliament's plenary session (Ospina, 2006; Kemitraan Indonesia, 2014). The failure in proposing the establishment of Ad-hoc Commission was continued by the Caucus and the CPLP (Community of Portuguese-Speaking Countries) through advocating the establishment of women's caucus in parliament in March 2006 (Costa , Sawer, \& Sharp, 2013; Ospina, 2006; Araujo, 2019). In the same year, Caucus through the Advocacy Working Group of Rede Feto was able to advocate the provision of electoral law that obliges the political party to include a woman in every four candidates 
in the list under the General Election Law No. 6/2006 of 28 December. This increased the women's share of seats in the 2012 election.

In 2009, Caucus claimed that the existing electoral legislation remains discriminatory against women; hence during the involvement of Caucus in the NGO Working Group on CEDAW Alternative Report requested by the CEDAW Committee, it raised this issue and made it as the national issue. There were two representatives from Caucus -Elda Barros and Laura Pina, who led the group to deliver the shadow report in Geneva and it was funded by UN (NGOs Working Group on CEDAW Alternative Report, 2009; Araujo, 2019). The report proclaimed that the existing law on general election limited the women candidacy in every group of four candidates instead of set the minimum number of women candidates in the list. The law also led to political party's tendency to list woman candidate in the last position. The report recommended the amendment of the law to reach the gender balance and substantive representation (NGOs Working Group on CEDAW Alternative Report, 2009). During the 44th Session of CEDAW Committee Meeting in New York, the CEDAW Committee concluded the observations on CEDAW Implementation in Timor-Leste. Regarding the General Election Law No. 6/2006, the CEDAW Committee recommended the Government of Timor-Leste to review the law and increase the number of women required (CEDAW Committee, 2009).

With the intensive advocacy effort led by Caucus under the Advocacy Working Group of Rede Feto and the support from the GMPTL has successfully made the law to be amended with the provision of the General Election Law No. 7/2011 on 22 June (Araujo, 2019). The new law requires one of the list of three candidates be a woman. It has increased the number of women candidates and elected women in 2012 election. The number of women candidates ran in the 2012 election was almost three times of the women candidates in the 2007 election, which is from 242 women candidates representing 14 political parties increased into 671 registered women from 21 political parties (SEPI, 2013 cited in Asian Development Bank, 2014). In addition, the elected women also increased up to $38.5 \%$ or equal to 25 seats of 
the total 65 seats contested in the 2012 election. In the last election of 2018, the women's representation slightly increased up to $40 \%$.

\section{b. Partner Role: Capacity Building for Women Candidates and Women MPs}

Besides advocating the policy change, Caucus also conducted the capacity building training that is supported by the other stakeholders in preparing women candidates prior to the election. This role is been explained by Lewis (2001), which is the other main roles of NGOs is partner which refers to be able to coworking with the government, donors, and private sectors in certain projects or activities (Lewis, 2001). Caucus carries out this role by partnering with political party and local women's organizations; governments through SEIGIS and GMPTL; and foreign donors, it can be the international organizations namely UNDP and IWDA, or foreign countries such as Japan and South Korea.

As it is mentioned previously, there are political party, GMPTL, and potential women candidates among the targets of Caucus. In the initial year, this NGO worked with UNTAET GAU to conduct political leadership training in 2001 in all 13 districts in Timor-Leste targeting to raise the awareness of woman as a voter and also as a potential candidate. Later in 2003, with the same purpose but in smaller level, Caucus became the key partner of UNIFEM's Programme for Enhancing Rural Women's Leadership and Participation in Nation Building in Timor-Leste (PERWL) (Ospina, 2006). The similar approach also reused for preparing the potential women candidates in 2007 election (Ospina, 2006). Caucus prepares them in form of community leaders. The materials given to the potential female leaders are, but not limited to good governance and transformative leadership in the context of Timor-Leste (Araujo, 2019).

The capacity building that aimed at targeting the women members of political parties started before the 2012 election. Indeed, not all political parties let Caucus to give the workshop targeting their women candidates. The training usually concerns on technical campaign and public speaking. The materials on the functions and roles of parliaments are also given to them.

"The political parties usually requested us to give them training in preparing the women candidates. The training is usually conducted in three phases; the first phase is conducted five years prior to the election or right after the parliamentary election was held; the second 
phase is usually conducted two years before the election after the party's leader selected the smaller number of potential female candidates; and the last phase is conducted after the party has come up with the fixed list of women candidates. Therefore, it is important for us to maintain a good communication with the political party. (Interview with Paula F. Corte Real de Araujo, Director of Caucus, 9 January 2019)"

Ms. Nelia Soares Menezes, one of the elected women in the 2018 election said that she joined one of programs conducted by Caucus (Menesez, 2019).

"T have attended one of the panel discussions on Youth Participation in Politics held by Caucus on April 2018 before I ran in the election representing the youth wings. (Interview with Nelia Soares Menezes, Elected Woman MP, 10 February 2019)"

In preparing the 2018 election, Caucus has initiated the other strategies after observing the 2012 election. It is true that due to the adoption of the new electoral legislation there was a significant increase of elected women in 2012 parliamentary election. But, Caucus argued that despite the policy change, women candidates still face inequality. The political parties tend to put women candidates in the last position of every list. Thus, conducting the capacity building is not enough. As Caucus has observed, the political party's tendency in prioritizing the men candidates is indicated due to two reasons. First is the strong patriarchal culture in Timor-Leste's society which reflected by the maledominated structure in the majority of political parties. By that, it hinders the woman candidates of being listed as number 1 and/or 2 in the list, because it will be filled automatically by the male party's leader and secretary general. Second reason is the misinterpretation towards the affirmative clause that written in the law. After the new electoral legislation passed and implemented in 2012 election, women candidates in majority were listed in the third position and its multiple $(3,6,9, \ldots)$ in every candidate list. Many political parties assumed that the affirmative clause obligated the women candidates to be listed in that position. Therefore, before the 2018 election, Caucus conducted the socialization from one party to other parties and also to GMPTL as the strategy to reconstructing the patriarchal culture and fixing the misinterpretation amongst the political parties on that matter (Araujo, 2019). In return, there were 
numbers of women listed not in the last position in every list of three in 2018 election.

In addition, Caucus and MOFFE also jointly organized a project funded by South Korea and Japan through UNDP Timor-Leste in 2018. The project is called Electoral Project (LEARN) (UNDP Timor-Leste, 2018). The project aimed at promoting women's participation in political parties. There were more than 150 women involved in the program and they were encouraged to involve themselves in political parties as candidates and party agents for election. Consequently, there was a small increase of women's representation in the 2018 election. Recently, Caucus and IWDA jointly organized the six months mentorship program for women MPs in Timor-Leste and Australia in order to share their experience and strengthen the role of women MPs in ensuring their voices on women's needs are taken into consideration and thus the policy outcome is gender sensitive (Araujo, 2019). This is also to prepare women MPs in the next parliamentary election.

Besides those programs organized by Caucus, the authors also highlight the personal innovative breakthrough that taken by the Director of Caucus, Paula F. Corte Real de Araujo. In order to successfully lead the Caucus for realizing its mission to increase the political participation of women, she voluntarily joins one of political parties in Timor-Leste. According to her view, political party is the first place where woman is determined whether they are able to or unable to participate in politics. Understanding more about the system within political party is essential in setting up the Caucus' strategy for increasing women's participation in politics. After sometime becoming a member of political party, she realized that discrimination against woman in political party does exist, particularly in decision making process. Recently, Caucus in partnership with other stakeholders is preparing the women members in political party to be ready for becoming the leader in political party in the next five years. By that, women will not be discriminated and able to participate in decisionmaking process (Araujo, 2019). 


\section{Conclusion}

Women's political participation and representation are essential to the realization of gender equality. The fight for women's political participation and representation is widespread rapidly in newly independent country such as TimorLeste. In Timor-Leste, timing was important because along with the nation building process, many international agencies and donors were promoting the norm of gender equality (Costa , Sawer, \& Sharp, 2013). This momentum is utilized effectively by local women's organizations to gain higher women's political participation and representation.

This article aimed to explore more about the role of local women's organizations in Timor-Leste, especially Caucus in seizing the momentum for increasing the involvement of women in politics. This research is expected to give a valuable contribution to the NGOs literature, and to the study on women's representation -gender and politics in a broad sense. The authors identify the crucial role of women's NGOs in promoting the women's political participation and representation, especially at national level through the given case study. The authors found that the presence of Caucus has successfully closed the gaps of government's lacking in promoting the political rights of Timorese women. Since its establishment, Caucus has a strong commitment in realizing gender equality in politics by raising the awareness of women on the importance of women's political participation and representation. Among the three main components of NGOs role defined by Lewis (2001), the authors argue that it is evident to say that Caucus has a catalyst and partner role in addressing this issue. First, Caucus has actively advocated the policy change on the electoral legislation intensively, and betokens a catalyst role. Second, Caucus is coworking with other stakeholders, such as government, political party and women's organization, and also donors for conducting capacity building denoted the partner role of Caucus. Additionally, Caucus was not established for delivering goods and services as it is not a humanitarian organization in its nature, and thus less signifies the implementer role.

The success of Caucus in increasing women's representation in TimorLeste's Parliament asserts the effectiveness of NGO. Caucus has the ability to influence the government to institutionalize women's rights and gender equality by 
proposing the creation of the parliamentary women's caucus. It is also able to bring the issue of gender equality in politics into national political arena and generate the impactful policy change of Electoral Law in 2011. Furthermore, it ensures that the Timorese women are aware of this issue through the capacity building that organized nationwide. This all proofs the relevance of the NGOs roles in modern society, which is not merely as a donor recipient organization.

\section{Acknowledgments}

We acknowledge the support from Rede Feto, Caucus Feto Iha Politika, Grupo das Mulheres Parlementares de Timor-Leste (GMPTL), and also Ms. Nelia Soares Menezes, an elected woman member of parliament of Timor-Leste. The authors would like to specially thank Ms. Elia da Costa Araujo, the colleague of authors working in semi-government organization of Timor-Leste, Comite 25.

\section{References}

\section{Books}

Anheier, H. K. (2005). Nonprofit Organizations: Theory, Management, Policy. New York: Routledge.

Ballington, J., \& Dahlerup, D. (2006). Gender Quotas in Post-Conflict States: East Timor, Afghanistan and Iraq. In D. Dahlerup (Ed.), Women, Quotas, and Politics. New York: Routledge.

IDEA. (2003). The Implementation of Quotas: Asian Experiences Quota Workshop Report Series. Stockholm: International Institute for Democracy and Electoral Assistance.

Keck, M. E., \& Sikkink, K. (1998). Activists Beyond Borders: Advocacy Networks in International Politics. Ithaca: Cornell University Press.

Kemitraan Indonesia. (2014). The Role of the Parliamentary Women's Caucus in Promoting Women's Participation and Representation: A Case Study in Indonesia and TimorLeste. Jakarta: Kemitraan Bagi Pembaruan Tata Pemerintahan.

Lewis, D. (2001). The Management of Non-Governmental Development Organizations: An Introduction. London and New York: Routledge. 
Lewis, D. (2010). Nongovermental Organizations, Definition and History. In H. K. Anheier, \& S. Toepler (Eds.), International Encyclopedia of Civil Society. New York: Springer.

Lewis, D. (2015). Non-Governmental Organizations and Civil Society. In A. Riaz，\& M. S. Rahman (Eds.), Routledge Handbook of Contemporary Bangladesh. London: Routledge.

Lewis, D., \& Kanji, N. (2009). Non-Governmental Organizations and Development. New York: Routledge.

Ospina, S. (2006). A Review and Evaluation of Gender-Related Activities of UN Peacekeeping Operations and Their Impact on Gender Relations in Timor-Leste. Dili: The United Nations Department of Peacekeeping Operations (DPKO) .

Ospina, S. (2006). Participation of Women in Politics and Decision Making in Timor-Leste: $A$ Recent History. Dili: United Nations Fund for Women (UNIFEM).

United Nations. (2007). Intergovernmental Negotiations and Decision Making at the United Nations: $A$ Guide (2nd updated ed.). New York: United Nations NonGovernmental Liaison Service (NGLS).

\section{Interviews}

Araujo, P. F. (2019, January 9). Director of Caucus Feto Iha Politika. (M. A.

Hidayahtulloh, Interviewer)

Exposto, A. (2019, January 9). Interim Executive Director of Rede Feto. (M. A. Hidayahtulloh, Interviewer)

Menesez, N. S. (2019, February 10). Elected Woman MP. (M. A. Hidayahtulloh, Interviewer)

\section{Journals}

Alvarez, S. E. (1999). Advocating Feminism: The Latin American Feminist NGO 'Boom'. International Feminist Journal of Politics, 1(2), 181-209.

Charlesworth, H., \& Wood, M. (2002). Women and Human Rights in the Rebuilding of East Timor. Nordic Journal of International Law, 71, 325-348.

Costa, M., Sawer, M., \& Sharp, R. (2013). Women Acting for Women. International Feminist Journal of Politics, 15(3), 333-352. 
Cummins, D. (2011). The Problems of Gender Quotas: Women's Representation on Timor-Leste's Suku Councils. Development in Practice, 20(1), 85-95.

Dahlerup, D., \& Freidenvall, L. (2005). Quotas as A 'Fast Track' to Equal Representation for Women. International Feminist Journal of Politics, 7(1), 2648.

Demirdöğen, Ü. (2012). The Role of International Organizations in the Adoption of Gender Quotas: Afghanistan and Iraq as Case Studies. Conference of the International Political Science Association. Madrid.

Dibie, J., \& Dibie, R. (2012). Non-Governmental Organizations (NGOs) and the Empowerment of Women in Africa. African and Asian Studies, 11, 95-122. Djuyandi, Y. (2016). The Role of Non-Governmental Organization (NGO) in Advocating the National Security Bill. Jurnal Bina Praja, 8(1), 163-173.

Elbers, W. (2016). Book Review: David Lewis: Non-Govermental Organizations, Management and Development, 3rd edn. International Journal of Voluntary and Nonprofit Organizations, 28(5).

Everett, J. (2011). Challenge and Co-optation: Women's Movements, NGOs, and Advocacy Coalitions in Asia. Critical Asian Studies, 33(3), 439-445.

Gwiazda, A. (2017). Women in Parliament: Assessing the Effectiveness of Gender Quotas in Poland. The Journal of Legislative Studies, 23(3), 326-347.

Hughes, M. M., Krook, M. L., \& Paxton, P. (2015). Transnational Women's Activism and the Global Diffusion of Gender Quota. International Studies Quarterly, 59, 357-372.

lieva, L. (2006). The NGO Role in Advocacy for the Human Rights of People with Disabilities in Bulgaria. Monitoring Human Rights and the Rule of Law in Europe.

Kareithi, R. N., \& Lund, C. (2012). Review of NGO Performance Research Published in Academic Journals between 1996 and 2008. South African Journal of Science, 108(11-12).

Keck, M. E., \& Sikkink, K. (2002). Transnational Advocacy Networks in International and Regional Politics. International Soial Science Journal, 51(159).

Kim, D. (2011). Catalysers in the Promotion of Migrants' Rights: Church-Based NGOs in South Korea. Journal of Ethnic and Migration Studies, 37(10), 1649-1667. 
Leung, Y. K., Leung, Y. W., \& Yuen, T. W. (2016). The Contribution of Advocacy NGOs in Governance through Cultivating of a Participatory Culture: Case Studies in Hong Kong. Universal Journal of Educational Research, 4(3), 490500.

Marcinkute, L. (2011). The Role of Human Rights NGO's: Human Rights Defenders or State Sovereignty Destroyers? Baltic Joutnal of Law \& Politics, 4(2), 52-77.

Nimu, A. (2018). Surviving Mechanism and Strategies of Gender Equality NGOs in Romania and Poland. Voluntas, 29, 310-332.

Nyamugasira, W. (1998). NGOs and Advoacacy: How Well Are the Poor Represented? Development in Practice, 8(3), 297-308.

Omungo, P. A. (2011). A Review of the Role of Civil Society in Advocacy and Lobbying for Enforcement of Health Policy in Kenya. African Population Studies, 25(1), 77-91.

Schwindt-Bayer, L. A. (2009, February). Making Quotas Work: The Effect of Gender Quota Laws on the Election of Women. Legislative Studies Quarterly, 34(1), $5-28$.

Tripp, A. M., \& Kang, A. (2008, March). The Global Impact of Quotas On the Fast Track to Increased Female Legislative Representation. Comparative Political Studies, 41(3), 338-361.

Verge, T. (2012). Institutionalizing Gender Equality in Spain: From Party Quotas to Electoral Gender Quotas. West European Politics, 35(2), 395-414.

Yoon, M. Y. (2001). Democratization and Women's Legislative Representation in SubSaharan Africa. Democratization, 8(2), 169-190.

\section{Laws and Government Policies}

Constitution of The Democratic Republic of Timor-Leste. (2002). Dili.

\section{Online Articles}

UNDP Timor-Leste. (2018, May 25). Encouraging women's political participation in TimorLeste. Retrieved January 20, 2019, from UNDP Timor-Leste: http://www.tl.undp.org/content/timor_leste/en/home/newscentre/arti 
cles/2018/encouraging-women-s-political-participation-in-timorleste.html

\section{Reports}

Asian Development Bank. (2005). Country Gender Assessment: Gender and Nation Building in Timor-Leste. Philippines: Asian Development Bank.

Asian Development Bank. (2014). Timor-Leste Country Gender Assessment. Mandaluyong City: Asian Development Bank.

Caucus Feto Iha Politika. (2017, September 21). Presentation. Participacao Mulher Na Politica. Dili.

CEDAW Committee. (2009). Concluding Observations of the Committee on the Elimination of Discrimination against Women: Timor-Leste. New York: CEDAW Committee. NGOs Working Group on CEDAW Alternative Report. (2009). NGOs Alternative Report: Implementation of the Convention on the Elimination of All Forms of Discrimination Against Women (CEDAW) in Timor-Leste. Dili: NGOs Working Group on CEDAW Alternative Report.

\section{Websites}

Rede Feto. (2019). Rede Feto Member Organizations. Retrieved January 28, 2019, from Rede Feto: http://www.redefeto.tl/page/members 